TEME, Vol. XLVI, Nº 2, April - June 2022, pp. 525-540

Review Article

Received: March 24, 2021

https://doi.org/10.22190/TEME210402045L

Revised: August 12, 2021

Accepted: August 31, 2021

Online First: October 13, 2021

\title{
INSURANCE MARKET DEVELOPMENT AND ECONOMIC GROWTH: EVIDENCE FROM WESTERN BALKANS REGION
}

\author{
Nemanja Lojalnica, Vladimir Stančić", Stevan Luković \\ University of Kragujevac, Faculty of Economics, Kragujevac, Serbia
}

\begin{abstract}
The basic objective of the paper is the examination of mutual interdependence of the parameters on insurance market and the economic growth at the specific area of exYugoslavia. Time horizon of the observation encompasses the period 2005-2019, and as the appropriate methodological framework, the econometrics of panel data was used. The accompanying co-integration tests and tests of long-term effects have shown that the insurance sector and economic growth are long-term related, as well as that the insurance sector exerts positive and statistically significant influence on the economic growth. Additionally, it was shown that non-life insurance realizes more significant effects on growth. To confirm robustness, causality test has shown that changes in insurance sector cause the changes in economic growth. Economic policy makers have an important task ahead of them, which consists in promoting insurance markets, improvement of regulation, and legislation framework that should contribute to the growth of economic activity in analyzed countries.
\end{abstract}

Key words: $\quad$ insurance development, economic growth, panel causality, ex-Yugoslavia

\section{РАЗВОЈ ТРЖИШТА ОСИГУРАЊА И ЕКОНОМСКИ РАСТ: ПРИКАЗ ЗЕМАЉА РЕГИОНА ЗАПАДНОГ БАЛКАНА}

\author{
Апстракт
}

Основни циљ рада је испитивање међусобне условљености параметара на тржишту осигурања и економског раста на специфичном подручју бивше Југославије. Временски хоризонт посматрања обухвата период 2005-2019. године, а као одговарајући методолошки оквир коришћена је економетрија панела. Пропратни тестови коинтеграције и дугорочних ефеката су показали да су сектор осигурања и економски раст дугорочно повезани, као и да сектор осигурања

* Corresponding author: Vladimir Stančić, University of Kragujevac, Faculty of Economics, Jovana Cvijića bb, 34000 Kragujevac, Serbia, vstancic@kg.ac.rs 
врши позитиван и статистички значајан утицај на економски раст. Додатно, показано је да неживотно осигурање остварује значајније ефекте по раст. За потврду робусности, тест каузалности је потврдио да промене у сектору осигурања изазивају промене у економском расту. Пред носиоцима економске политике је важан задатак који се састоји у промовисању тржишта осигурања, унапређењу регулативе и законодавног оквира, који би требали да допринесу расту привредне активности у анализираним земљама.

Кључне речи: развој тржишта осигурања, економски раст, панел каузалност, екс- Југославија

\section{INTRODUCTION}

It is generally accepted that the main functions of insurance are direct and indirect protection, mobilization and allocation of monetary funds and social function. Therefore, insurance is equally important for individuals, businesses and governments. The study of the European Committee in the field of insurance, and previous scientific studies, pointed out that the insurance industry affects economic growth through the following: (1) offering protection to companies and individuals for covering damages that are provoked by destructive forces of nature and human action, (2) facilitating commercial transactions and the provision of credit by mitigating losses, (3) promoting entrepreneurship, encouraging innovations, investment, market development and competition, (4) increasing financial intermediation through life insurance products and (5) enabling risk averse individuals and companies to undertake higher return activities (Cristea, Marcu, \& Cârstina, 2014; Peleckienè, Peleckis, Dudzevičiūte \& Peleckis, 2019).

In a broader sense, it could be said that insurance business has a positive impact on economic development and vice versa. As a developed insurance market stimulates economic growth of a country, the level of its economic growth affects insurance business development in return. Over the last two decades, significant attention has been paid to the evaluation of the relationship between financial development and economic growth. Most of those studies are related to the banking sector and financial markets. However, in the last years, the insurance sector received a growing attention. The nature of causality between the insurance market development and economic growth, and how these categories affect each other, has become a debatable issue. This paper deals with the relationship between the key economic factors and development of the insurance sectors in a specific region of the Western Balkans, called ex-Yugoslavia, which includes Slovenia, Croatia, Serbia, Montenegro, North Macedonia and Bosnia and Herzegovina. There is a very interesting point of view in the historical sense, because these countries have a similar historical heritage, but today they are completely independent and significantly different. As an additional specificity of this region, with the disintegration of the former common state, Slovenia belonged to another region in relation to other countries. Nowadays, Slovenia is a part of the Central Eu- 
ropean region, but it will be included into the research because of its exYugoslavia background.

This research attempts to provide a more reliable assessment of the relationship between insurance development and economic growth in these countries using annual data from 2005 to 2019. The results can be useful for institutions and regulators of financial systems, economic analysts and other subjects in these countries, in order to detect and forecast insurance market development trends and possible measures to encourage it. This paper consists of five parts. After the introductory part and literature review, there is a description of the methodology and data used. The part that follows is dedicated to empirical results, and the last part contains the concluding remarks and some possible research directions.

\section{LITERATURE REVIEW}

Researchers have examined causality between insurance market development and economic growth at different levels and from different points of view - from the whole world to individual countries and from the entire insurance markets to the specific types of insurance. Table 1 presents the studies which investigated the relationship between the development of the insurance market and economic growth. The main findings confirmed the positive impact of the (life) insurance market on economic growth.

Table 1. Link between insurance parameters and economic growth

\begin{tabular}{|c|c|c|c|c|}
\hline Study & $\begin{array}{l}\text { Time } \\
\text { period }\end{array}$ & $\begin{array}{l}\text { No. of } \\
\text { countries }\end{array}$ & Methodolog & Result \\
\hline Arena (2008) & $\begin{array}{l}1974- \\
2004\end{array}$ & 55 & GMM & $\begin{array}{l}\text { Life insurance } \rightarrow \text { economic growth } \\
\text { Non-life insurance } \rightarrow \text { economic growth }\end{array}$ \\
\hline $\begin{array}{l}\text { Sümegi } \\
\text { (2008) }\end{array}$ & $\begin{array}{l}1992- \\
2005\end{array}$ & $\begin{array}{c}29 \\
\text { European }\end{array}$ & $\begin{array}{l}\text { Panel } \\
\text { regression }\end{array}$ & Life insurance $\rightarrow$ economic growth \\
\hline $\begin{array}{l}\text { Ćurak, } \\
\text { Lončar \& } \\
\text { Poposki } \\
(2009)\end{array}$ & $\begin{array}{l}1992- \\
2007\end{array}$ & $\begin{array}{c}10 \\
\text { transition } \\
\text { EU }\end{array}$ & $\begin{array}{l}\text { Panel } \\
\text { fixed- } \\
\text { effect }\end{array}$ & Insurance $\rightarrow$ economic growth \\
\hline $\begin{array}{l}\text { Ilhan \& } \\
\text { Bahadir } \\
\text { (2011) }\end{array}$ & $\begin{array}{l}1999- \\
2008\end{array}$ & 29 & $\begin{array}{l}\text { Panel } \\
\text { regression }\end{array}$ & Insurance $\rightarrow$ economic growth \\
\hline $\begin{array}{l}\text { Chen, Lee \& } \\
\text { Lee (2012) }\end{array}$ & $\begin{array}{l}1976- \\
2005\end{array}$ & 60 & GMM & Life insurance $\rightarrow$ economic growth \\
\hline $\begin{array}{l}\text { Chang, Lee } \\
\text { \& Chang } \\
\text { (2014) }\end{array}$ & $\begin{array}{l}1979- \\
2006\end{array}$ & $\begin{array}{c}10 \\
\text { OECD }\end{array}$ & $\begin{array}{l}\text { Granger } \\
\text { bootstrap }\end{array}$ & Insurance $\rightarrow$ economic growth \\
\hline $\begin{array}{l}\text { Stančić \& } \\
\text { Lojanica } \\
(2020)\end{array}$ & $\begin{array}{l}2003- \\
2019\end{array}$ & $\begin{array}{c}12 \\
\text { European } \\
\text { emerging }\end{array}$ & $\begin{array}{l}\text { Granger } \\
\text { causality }\end{array}$ & Insurance $\rightarrow$ economic growth \\
\hline
\end{tabular}


Zouhaier (2014) conducted research on 23 OECD countries using panel data model with fixed effect in the period 1990-2011. He observed the insurance industry in total, but also life and non-life sectors in particular. He found a negative effect of aggregate and non-life insurance on economic growth when measured by the insurance density. On the other hand, non-life insurance has significant positive impact on economic growth, when measured by the penetration rate. Peleckiene, Peleckis, Dudzevičiūtė \& Peleckis (2019) examined the relationships between insurance and economic growth across the $27 \mathrm{EU}$ countries, over the period of 2004-2015. They detected a positive statistically significant relationship between insurance penetration and economic growth in Luxembourg, Denmark, Netherlands and Finland. Besides, a negative statistically significant relationship has been identified in Austria, Belgium, Malta, Estonia and Slovakia. The main econometric method was the Granger test that has shown unidirectional causality running from GDP to insurance in Luxembourg and Finland and unidirectional causality from insurance to GDP in Netherlands, Malta and Estonia. The case of Austria has shown bidirectional causality between the variables and in Slovakia results has shown the absence of causality between them.

To the best of our knowledge, there are only a few published articles concerning the specific region, which will be researched in this paper. Njegomir \& Stojić (2010) tested the interaction between economic growth and insurance in the ex-Yugoslavia region, but relative to this paper, they excluded Montenegro. Using the Granger test and fixed effects models for panel data for the period 2004-2008, they concluded that the insurance sector development positively and significantly affects economic growth. Novović Burić, Cerović Smolović, Lipovina Božović \& Lalević Filipović (2017) used panel data model in period 2005-2015 for 6 Western Balkan countries (relative to this paper they included Albania and excluded Slovenia) to indicate the main economic factors that have important influence on the purchase of life insurance products. The results showed that the GDP and wages have significant and positive impact on the demand for life insurance (measured by total life insurance premium), while the impact of unemployment rate and interest rate is negative.

The review of recent studies has shown that there are only a few studies conducted on the insurance markets of the Western Balkans. Still, much more interest was shown for the development of the banking sector in countries of this region (recently, Kalaš, Mirović, Milenković \& Andrašić, 2020). 


\section{DATA AND METHODOLOGY}

The following variables will be used in the paper: three variables related to the insurance density (gross insurance premium per capita (GIPPC), gross life insurance premium per capita (GIPPC_life) and gross non-life insurance premium per capita (GIPPC_non-life)), then three variables related to the penetration rate (participation of insurance premium in gross domestic product (PENE), participation of life insurance premium in gross domestic product (PENE_life) and participation of non-life insurance premium in gross domestic product (PENE_non-life)), as well as two macroeconomic indicators (gross domestic product per capita (GDPPC) and the level of trade openness of the economy (OPEN)). Within the database of international institutions, data on variables related to the insurance sector are not available for all the countries that are the subject of our analysis. For instance, the countries of former Yugoslavia, according to the statistical base of respectable Swiss Re Institute and their publication Sigma, belong to the domain of developing European insurance markets. However, only Slovenia, Croatia, and Serbia are listed within emerging EMEA (Europe, Middle East and Africa), while the other countries are included within "other countries" of that segment of world market. For such reason, data on the indicators of insurance market are taken from the official web sites of state insurance agencies (Slovenian Insurance Association, Croatian Insurance Bureau, Insurance Supervision Agency - Montenegro, Insurance Supervision Agency of North Macedonia, Insurance Agency of Bosnia and Herzegovina and Insurance

Table 2. Descriptive statistics results

\begin{tabular}{|c|c|c|c|c|c|c|c|c|c|}
\hline Variable & & GDPPC & GIPPC & $\begin{array}{c}\text { GIPPC_ } \\
\text { life }\end{array}$ & $\begin{array}{l}\text { GIPPC_ } \\
\text { non-life }\end{array}$ & OPEN & PENE & $\begin{array}{c}\mathrm{PENE}_{-} \\
\text {life }\end{array}$ & $\begin{array}{l}\text { PENE } \\
\text { non-life }\end{array}$ \\
\hline \multicolumn{10}{|l|}{ Country } \\
\hline \multirow{3}{*}{ Serbia } & 1 & 13937.14 & 107.87 & 20.59 & 87.28 & 88.09 & 1.91 & 0.36 & 1.56 \\
\hline & 2 & 2654.28 & 20.51 & 8.76 & 14.27 & 14.82 & 0.11 & 0.12 & 0.13 \\
\hline & 3 & 0.14 & 0.04 & 0.72 & 0.21 & 1.19 & 0.74 & 1.16 & 0.15 \\
\hline \multirow{3}{*}{ Montenegro } & 1 & 15095.83 & 135.51 & 19.58 & 115.93 & 109.01 & 1.98 & 0.27 & 1.71 \\
\hline & 2 & 3731.11 & 29.26 & 8.37 & 21.39 & 10.08 & 0.14 & 0.10 & 0.11 \\
\hline & 3 & 0.28 & 5.14 & 1.98 & 5.74 & 4.40 & 1.27 & 3.67 & 0.51 \\
\hline \multirow{3}{*}{$\begin{array}{l}\text { North } \\
\text { Macedonia }\end{array}$} & 1 & 12396.16 & 73.01 & 7.18 & 65.83 & 109.96 & 1.55 & 0.14 & 1.41 \\
\hline & 2 & 2902.54 & 11.22 & 5.02 & 7.21 & 15.10 & 0.11 & 0.08 & 0.17 \\
\hline & 3 & 0.50 & 0.05 & 1.17 & 1.13 & 0.23 & 2.50 & 1.31 & 1.52 \\
\hline \multirow{3}{*}{ Slovenia } & 1 & 30750.48 & 1281.20 & 402.01 & 879.11 & 140.35 & 5.51 & 1.73 & 3.79 \\
\hline & 2 & 4693.24 & 160.11 & 64.99 & 99.45 & 13.84 & 0.31 & 0.16 & 0.18 \\
\hline & 3 & 1.55 & 0.93 & 0.52 & 1.41 & 0.41 & 1.29 & 1.08 & 1.86 \\
\hline \multirow{3}{*}{ Croatia } & 1 & 22015.17 & 364.46 & 104.42 & 260.05 & 86.68 & 2.69 & 0.77 & 1.91 \\
\hline & 2 & 3890.61 & 46.58 & 11.97 & 38.96 & 9.60 & 0.12 & 0.05 & 0.15 \\
\hline & 3 & 0.60 & 0.30 & 3.80 & 0.39 & 0.67 & 1.39 & 1.00 & 1.86 \\
\hline \multirow{3}{*}{$\mathrm{B} \& \mathrm{H}$} & 1 & 10767.26 & 85.58 & 14.59 & 70.99 & 89.87 & 2.01 & 0.33 & 1.68 \\
\hline & 2 & 2711.27 & 19.88 & 6.16 & 13.93 & 7.67 & 0.11 & 0.09 & 0.09 \\
\hline & 3 & 0.65 & 0.41 & 0.76 & 0.39 & 0.11 & 0.88 & 1.28 & 1.95 \\
\hline
\end{tabular}

1-Mean; 2- Standard deviation; 3-Jarque-Bera test. Source: Author's calculations 
Supervision Department of National Bank of Serbia). Variables related to the penetration rate are expressed in percents, while those related to the insurance density are expressed in US dollars. In order to present the level of economic activity in the most appropriate way, GDPPC was measured by the purchasing power parity, in international dollars, and data on its flow are available within database of World Bank (WDI, 2020). In order to avoid the potential bias problem, an additional OPEN variable was included in the analysis, which was expressed in percents as a share of total import and export of national economy in GDP (WDI, 2020).

Time horizon covers the period from 2005, when the majority of analyzed countries started regular reporting from the insurance market, to (last available) 2019. In the empirical analysis, the balanced panel was used, and it has total of 90 observations. Since the time horizon covering a period of 15 years $(T=15)$ is larger than number of observation units $(\mathrm{N}=6)$, the appropriate methodology including examination of panel cointegration and panel causality (Breitung \& Pesaran, 2005) will be applied in the paper. Table 2 shows the descriptive statistics of indicators. It can be pointed out that the economies with higher average GDPPC invest on average more assets into the insurance sector, i.e. they are more active on this market. Due to statistical reasons, the variables are converted into the logarithm form and marked with small letters (gdppc, open, gippc, gippc_life, gippc_non-life, pene, pene_life, pene_non-life). Dependence of the economic growth and insurance sector can be shown in the following way:

$$
g_{d p p c}=\theta_{i t}+\beta_{1} x_{i t}+\beta_{2} \text { open }_{i t}+\varepsilon_{i t}
$$

where $i=1,2, \ldots, \mathrm{N}$ is the index of the country, $t=1,2, \ldots, \mathrm{T}$ is the time index, $\beta_{1}$, and $\beta_{2}$ indicates the long-term effects of the independent on the dependent variable, $\theta_{i}$ is country-specific fixed effect, while $\varepsilon_{i t}$ is error term. In this case, $x$ represents the independent variable, which is related to the insurance sector (gippc, gippc_life, gippc_non-life, pene, pene_life, pene_non-life). The total of six models will be tested in the paper: first, the independent $x$ will be represented in form of gippc, then in the second model as gippc_life, in the third model as gippc_non-life, in the fourth pene, in the fifth pene_life, and in the sixth pene_non-life. Taking into account that potential existence of common shocks among selected countries could result in creating contemporaneous correlation, it is very important to specify cross-sectional dependencies. Breusch \& Pagan (1980) suggested LM test, which can be shown in the following form:

$$
L M=T \sum_{i=1}^{N-1} \sum_{j=i+1}^{N} \hat{\rho}_{i j}^{2}
$$

where the sample assessment is pairwise of the residual correlation, obtained from the equation 1, by applying OLS model, for any $i$. Under 
the null hypothesis, LM statistics is characterized by chi square distribution with $\mathrm{N}^{*}(\mathrm{~N}-1) / 2$ degrees of freedom. In order to check the robustness of the results, Pesaran (2004) cross-section dependence test was also used. Having taken into account that the literature dealing with issues of panel data has shown that economic indicators express significant interdependence among countries, i.e. the presence of common shocks, it imposes the use of specific tests of unit root in empirical procedures. In this regard, the second generation stationarity test proposed by Pesaran (2007) will be used.

Long-term connection of variables was tested by using JohansenFisher panel combined cointegration test. Maddala \& Wu (1999) using Johansen cointegration test have considered Fisher's suggestion to perform combining individual tests and suggested alternatives to trace statistics and Max-eigen statistics for testing cointegration in the panel. They combined individual results for every unit of observation. Basic precondition for using this test is that analyzed variables have the order of integration one (i.e. I(1)), i.e. that they are stationary after conversion into the first difference. After testing cointegration, the evaluation of the longrun parameters is carried out with the help of the panel Dynamic Ordinary Least Square (DOLS) developed by Pedroni (2001). This approach allows greater flexibility in the case of presence of heterogeneous cointegration vectors. Dynamic OLS in the panel model can be shown in the following form:

$$
y_{i t}=\alpha_{i}+\beta x_{i t}+\sum_{j=-p_{i}}^{p_{i}} \phi_{i j} \Delta x_{i t-j}+\varepsilon_{i t}
$$

where $\phi_{i j}$ represents the coefficients of the lead and lag differences, which accounts for the possible serial correlation and endogeneity of the regressor(s), thus yielding unbiased estimates, while $\pm p_{i}$ is the number of lags and leads. DOLS generates unbiased estimates for cointegrating variables, even with endogenous regressors, which is a very important feature of this procedure. In order to check the robustness of the results, an FMOLS model was also tested. To determine causality in this panel study, the Granger test of non -causality, developed by Dumitrescu \& Hurlin (2012) will be used. In short, this is a statistical test based on the Wald statistics that is averaged between the units of the cross-section data. Specifically, this method involves testing of the causal relations for each country individually, while the cross-section data are used to improve the model specifications as well as the power of the test (HoltzEakin, Newey \& Rosen, 1998). It is important to emphasize that Dumitrescu \& Hurlin (2012) have shown that standardized panel statistics also has very good characteristics on samples of smaller extent, even in situations when interdependence of observation units is present. 


\section{EMPIRICAL RESULTS}

The results of Breusch-Pagan LM and Pesaran CD tests are shown in Table 3. The testing is based on the null hypothesis that there is no crossdependence of panel data. The results show that the null hypothesis, in all models, with the significance level of $1 \%$, cannot be accepted, which implies the presence of cross-dependence of panel data. The obtained result means that in case of negative (positive) economic event in some of ex-YU countries the effect is transferred to other ex-YU countries.

Table 3. Cross sectional dependence tests

\begin{tabular}{lcc}
\hline Model & Test & Test statistics \\
\hline gdppc $=$ f(gippc, open $)$ & Breusch- Pagan LM & $75.33^{*}$ \\
gdppc $=$ f(gippc, open $)$ & Pesaran CD & $5.25^{*}$ \\
gdppc $=$ f(gippc_life, open $)$ & Breusch- Pagan LM & $76.18^{*}$ \\
gdppc $=$ f(gippc_life, open $)$ & Pesaran CD & $1.74^{* * *}$ \\
gdppc $=$ f(gippc_non-life, open $)$ & Breusch- Pagan LM & $74.28^{*}$ \\
gdppc $=$ f(gippc_non-life, open $)$ & Pesaran CD & $6.65^{*}$ \\
gdppc $=$ f(pene, open $)$ & Breusch- Pagan LM & $134.58^{*}$ \\
gdppc $=$ f(pene, open $)$ & Pesaran CD & 11.39 \\
gdppc $=$ f(pene_life, open $)$ & Breusch- Pagan LM & $75.70^{*}$ \\
gdppc $=$ f(pene_life, open $)$ & Pesaran CD & $3.24^{*}$ \\
gdppc $=$ f(gippc_non-life, open $)$ & Breusch- Pagan LM & $90.43^{*}$ \\
gdppc $=$ f(gippc_non-life, open $)$ & Pesaran CD & $9.31^{*}$ \\
\hline
\end{tabular}

Note: ${ }^{*},{ }^{* *}$ and ${ }^{* * *}$ indicates significance at the $1 \%, 5 \%$ and $10 \%$ levels, respectively. Source: Author's calculations

In Table 4, the results of unit root test for analyzed variables are presented. Pesaran (2007) test is based on the null hypothesis that the variables have unit root. Following the test results on the level data, the null hypothesis is not rejected in any case. In the contrast, after converting

Table 4. Results of the panel unit root test

\begin{tabular}{lllllll}
\hline Series & \multicolumn{6}{c}{ PESCADF (constant) } \\
\cline { 2 - 7 } & \multicolumn{5}{c}{ Levels } & \multicolumn{5}{c}{ First difference } \\
\cline { 2 - 7 } & t-bar test & cv5 & cv1 & t-bar test & cv5 & cv1 \\
\hline gdppc $_{\text {it }}$ & -2.16 & -2.37 & -2.66 & -4.15 & -2.37 & -2.66 \\
gippc $_{\text {it }}$ & -0.13 & -2.37 & -2.66 & -3.63 & -2.37 & -2.66 \\
gippc_life $_{\text {it }}$ & -1.98 & -2.37 & -2.66 & -2.89 & -2.37 & -2.66 \\
gippc_non-life $_{\text {it }}$ & -0.71 & -2.37 & -2.66 & -307 & -2.37 & -2.66 \\
open $_{\text {it }}$ & -0.98 & -2.37 & -2.66 & -2.64 & -2.37 & -2.66 \\
pene $_{\text {it }}$ & -1.63 & -2.37 & -2.66 & -2.59 & -2.37 & -2.66 \\
pene_life $_{\text {it }}$ & -2.35 & -2.37 & -2.66 & -2.87 & -2.37 & -2.66 \\
pene_non-life $_{\text {it }}$ & -1.66 & -2.37 & -2.66 & -2.93 & -2.37 & -2.66 \\
\hline \multicolumn{5}{c}{ Notes: cv5 and cv1 are critical value at 5 and 1\%, respectively. } \\
\multicolumn{5}{c}{ Source: Author's calculations } \\
\end{tabular}


variables into the first difference, the null hypothesis is not accepted in any case. The acceptance of alternative hypothesis on the first difference, leads to the conclusion that all observed variables are stationary and that the results are statistically significant. All the variables have order of integration one, which is a precondition for performing Johansen-Fisher panel cointegration test.

The results of cointegration panel test are shown in Table 5. The null hypothesis that is tested first, is based on the assumption that there is no cointegration among variables $(\mathrm{r}=0)$, then the hypothesis that no more than one cointegration vector is present $(r<=1)$ is tested and in the end the hypothesis that no more than two cointegration vectors are present $(\mathrm{r}<=2)$ is tested. In the first two cases null hypothesis $(r=0, r<=1)$ cannot be accepted, while the trace statistics and Max-Eigen statistics in all six examined models accept null hypothesis on the existence of no more than two cointegration vectors. Such obtained results imply the existence of longterm connection of variables in models $1,2,3,4,5$, and 6 .

Table 5. Panel cointegration test results

\begin{tabular}{|c|c|c|c|}
\hline \multicolumn{4}{|c|}{ 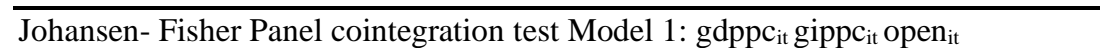 } \\
\hline & $\mathrm{r}=0$ & $\mathrm{r}<=1$ & $\mathrm{r}<=2$ \\
\hline Trace statistic & $104.6^{*}$ & $33.58^{*}$ & 9.74 \\
\hline Max-Eigen statistic & $88.08^{*}$ & $35.35^{*}$ & 9.74 \\
\hline \multicolumn{4}{|c|}{ Johansen- Fisher Panel cointegration test Model 2: gdppc $_{i t}{\text { gippc } \text { life }_{i t} \text { open }_{i t}}$} \\
\hline & $r=0$ & $\mathrm{r}<=1$ & $\mathrm{r}<=2$ \\
\hline Trace statistic & $101.4^{*}$ & $44.32^{*}$ & 15.24 \\
\hline Max-Eigen statistic & $79.24^{*}$ & $26.91^{*}$ & 15.24 \\
\hline \multicolumn{4}{|c|}{$\begin{array}{l}\text { Johansen- Fisher Panel cointegration test Model 3: } \text { gdppc }_{\text {it }} \\
\qquad \mathrm{r}=0\end{array}$} \\
\hline Trace statistic & $95.43^{*}$ & $31.57^{*}$ & 9.35 \\
\hline Max-Eigen statistic & $79.93^{*}$ & $33.91^{*}$ & 9.35 \\
\hline \multicolumn{4}{|c|}{ Johansen- Fisher Panel cointegration test Model 4: gdppc $_{\text {it }}$ pene $_{\text {it }}$ open $_{\text {it }}$} \\
\hline Trace statistic & $47.29^{*}$ & $26.44^{*}$ & 10.86 \\
\hline Max-Eigen statistic & $29.13^{*}$ & $26.96^{*}$ & 10.86 \\
\hline \multicolumn{4}{|c|}{ Johansen- Fisher Panel cointegration test Model 5: gdppc ${ }_{\text {it }}$ pene_life $_{\text {it }}$ open $_{\text {it }}$} \\
\hline & $r=0$ & $\mathrm{r}<=1$ & $r<=2$ \\
\hline Trace statistic & $101^{*}$ & $29.46^{\text {** }}$ & 16.04 \\
\hline Max-Eigen statistic & $97.65^{*}$ & $24.29^{* *}$ & 16.04 \\
\hline Johansen- Fisher Pa & $\begin{array}{c}\text { ointegrati } \\
\mathrm{r}=0\end{array}$ & $\begin{aligned} \text { 16: gdpp } \\
\mathrm{r}<=1\end{aligned}$ & $\begin{array}{l}-\mathrm{life}_{\text {it }} \text { open }_{\text {it }} \\
\mathrm{r}<=2\end{array}$ \\
\hline Trace statistic & $45.45^{*}$ & 16.78 & 14.37 \\
\hline Max-Eigen statistic & $41.14^{*}$ & 15.07 & 14.37 \\
\hline
\end{tabular}

Notes: The Johansen- Fisher test has $\chi^{2}$ distribution with $2 \mathrm{~N}$ degrees of freedom. Source: Author's calculations 
When examining long-term effects that insurance sector has on economic growth, DOLS and FMOLS models were used. In Table 6, the

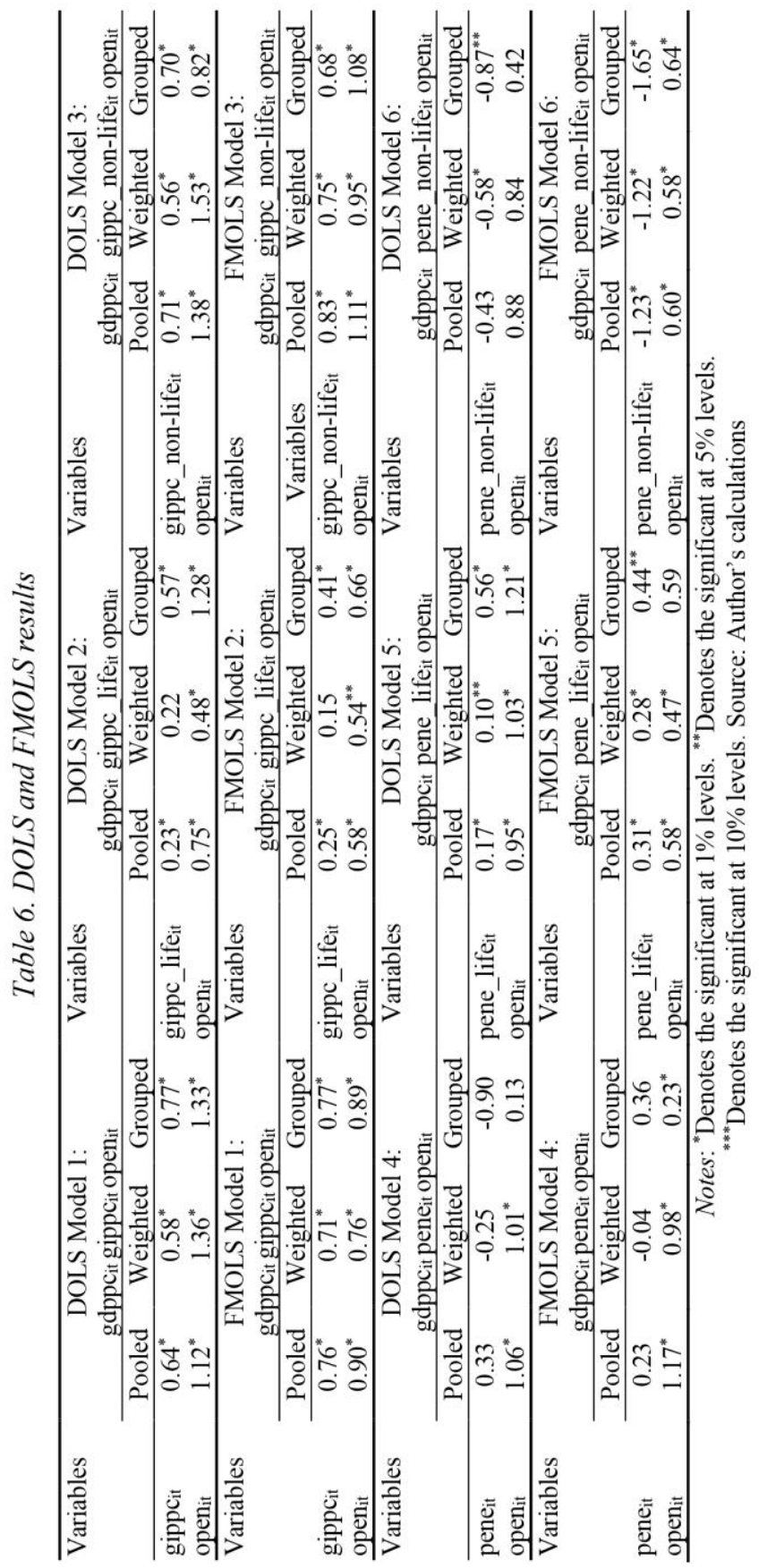


results of long-term effects of insurance sector and trade openness on the economic growth are shown. It is indicative that a positive and statistically significant connection between economic growth and parameters related to the insurance sector is positive. If Model 1 is observed, according to DOLS model, it is noticeable that the increase of gippc leads to the growth of gdppc, and the appropriate coefficient of elasticity ranges within 0.58-0.77. FMOLS model confirms the positive connection, but the appropriate coefficient ranges within 0.71-0.76. In Model 2, the effect of gippc_life in DOLS model ranges within 0.22-0.57, while in FMOLS model the appropriate coefficient ranges within 0.25-0.41. In the Model 3, gippc_non-life realize positive impact on gdppc, and it is expressed by the elasticity coefficient ranging within $0.56-0.70$ in DOLS model, and $0.68-0.83$ in FMOLS model. It should be mentioned that the insurance density in all observed countries grew in the analyzed period, and in those with a low starting position, it grew even dramatically. This is very important in the context of further fostering of economic activity in these countries. The structure of this indicator, i.e. clear dominant position of non-life insurance, speaks in favor of the established more significant impact of non-life insurance compared to life insurance.

Unlike Models 1, 2 and 3 that give quite unambiguous results, Models 4, 5, and 6 have no such characteristics. Primarily, in Model 4, no statistically significant connection between pene and gdppc was established, both in DOLS and in FMOLS model. The results of Model 5 are the only ones in accordance with those in Models 1-3 and it was shown that pene_life exerts positive and statistically significant impact on gdppc. That influence is reflected in DOLS model in the elasticity coefficient, which ranges within 0.10-0.56, and in FMOLS model ranges within 0.280.44 . On the other hand, in Model 6, the negative effect of pene_non-life on gdppc was established, where by applying DOLS model it was shown that one-percent increase of pene_non-life leads to fall in range within 0.43-0.87, while in FMOLS model the appropriate coefficient also has negative sign and it ranges within -1.22-1.65.

The structure of penetration rate reflects a clear dominance of nonlife insurance compared to life insurance in observed countries. Still, the largest portion of the non-life insurance premium is realized based on compulsory insurances (for example, in Serbia 33\%, in Montenegro 40\%, in North Macedonia 43\%, and in Bosnia and Herzegovina even 50\% of total premium in 2019 was realized based on only one type of insurance motor third party liability insurance). Thus, non-life insurance can be related to the aspect of necessary (of even compulsory) goods, which implies that each shift of life insurance is a more probable indicator of the increase of life standard of the members of social community. Until the end of the analyzed period, the relationship of life and non-life insurance in observed countries, measured by penetration rate, changed in favor of 
life insurance. By observing the opposite direction, a significant impact of economic growth on the insurance market was established only in case of life insurance penetration rate. Non-life insurance in stated countries was, to a significant extent, conditioned by regulatory obligation of insurance of individual activities. Thus, life insurance, due to its voluntary nature, in emerging countries, is to some extent treated as a lucrative good as well, so that it is in direct dependence on the degree of development of the social community itself.

Table 7 shows the results of panel causality developed by Dumitrescu \& Hurlin (2012) for all 6 models. The test is based on the null hypothesis that a selected variable does not cause the change of other variable. It was also established that changes in insurance density lead to the changes in economic growth, i.e. gippc, gippc_life, and gippc_non-life cause changes in gdppc. The obtained results are statistically significant, with the

Table 7. Panel causality test results

Pairwise Dumitrescu Hurlin Panel Causality Test Lag 1 is determined by Akaike Information Criterion

\begin{tabular}{|c|c|c|c|}
\hline $\mathrm{H}_{0}$ & $\begin{array}{c}\mathrm{W}- \\
\text { Statistics }\end{array}$ & $\begin{array}{c}\text { Zbar- } \\
\text { Statistics } \\
\end{array}$ & Probability \\
\hline open $_{\text {it }}$ does not homogeneously cause gdppc $_{\text {it }}$ & 5.48 & 5.05 & $0.00^{*}$ \\
\hline gdppcit does not homogeneously cause open $_{\text {it }}$ & 1.74 & 0.61 & 0.54 \\
\hline gippc $_{\text {it }}$ does not homogeneously cause gdppc ${ }_{i t}$ & 8.36 & 8.46 & $0.00^{*}$ \\
\hline gdppc $_{\text {it }}$ does not homogeneously cause gippc ${ }_{i t}$ & 2.43 & 1.4 & 0.15 \\
\hline gippc $_{\text {it }}$ does not homogeneously cause open ${ }_{\text {it }}$ & 2.84 & 1.92 & $0.06^{* * *}$ \\
\hline open $_{\text {it }}$ does not homogeneously cause gippc $c_{i t}$ & 2.35 & 1.33 & 0.18 \\
\hline gippc_life ${ }_{i t}$ does not homogeneously cause gdppc $c_{i t}$ & 6.93 & 6.77 & $0.00^{*}$ \\
\hline gdppc $_{\text {it }}$ does not homogeneously cause gippc_life & 2.00 & 0.92 & 0.36 \\
\hline gippc_life ${ }_{i t}$ does not homogeneously cause open ${ }_{i t}$ & 2.69 & 1.74 & $0.08^{* * *}$ \\
\hline open $_{i t}$ does not homogeneously cause gippc_life & 2.92 & 2.01 & $0.04^{* *}$ \\
\hline gippc_non-life $e_{i t}$ does not homogeneously cause gdppc $_{i t}$ & 8.51 & 8.64 & $0.00^{*}$ \\
\hline gdppcit does not homogeneously cause gippc_non-life & 1.61 & 0.46 & 0.64 \\
\hline gippc_non-life it $_{\text {does not }}$ homogeneously cause open ${ }_{\text {it }}$ & 3.37 & 2.54 & $0.01^{* *}$ \\
\hline open $_{\text {it }}$ does not homogeneously cause gippc_non-life ${ }_{i t}$ & 1.55 & 0.39 & 0.70 \\
\hline pene $_{i t}$ does not homogeneously cause gdppcit & 7.81 & 7.81 & $0.00^{*}$ \\
\hline gdppc $_{\text {it }}$ does not homogeneously cause pene ${ }_{i t}$ & 0.66 & -0.66 & 0.51 \\
\hline pene $_{i t}$ does not homogeneously cause open ${ }_{i t}$ & 2.30 & 1.28 & 0.20 \\
\hline open $_{\text {it }}$ does not homogeneously cause pene ${ }_{i t}$ & 1.23 & 0.02 & 0.99 \\
\hline pene_life ${ }_{i t}$ does not homogeneously cause gdppcit & 2.35 & 1.33 & 0.18 \\
\hline gdppc $_{\text {it }}$ does not homogeneously cause pene_life ${ }_{i t}$ & 1.74 & 0.61 & 0.54 \\
\hline pene_life it $_{\text {does not homogeneously cause open }}$ it & 4.69 & 4.11 & $0.00^{*}$ \\
\hline open $_{\text {it }}$ does not homogeneously cause pene_life ${ }_{i t}$ & 1.53 & 0.36 & 0.71 \\
\hline pene_non-life ${ }_{i t}$ does not homogeneously cause $\mathrm{gdppc}_{\mathrm{it}}$ & 4.36 & 3.71 & $0.00^{*}$ \\
\hline gdppc $_{\text {it }}$ does not homogeneously cause pene_non-life ${ }_{i t}$ & 0.43 & -0.94 & 0.35 \\
\hline pene_non-life ${ }_{i t}$ does not homogeneously cause open ${ }_{\text {it }}$ & 2.12 & 1.07 & 0.28 \\
\hline open $_{i t}$ does not homogeneously cause pene_non-life & 2.04 & 0.97 & 0.33 \\
\hline
\end{tabular}

Notes: ${ }^{*}$ Denotes the significant at $1 \%$ levels. ${ }^{* *}$ Denotes the significant at $5 \%$ levels. *** Denotes the significant at $10 \%$ levels. Source: Author's calculations 
significance level of $1 \%$. However, the connection of mentioned variables is one-way and vice versa is not valid, i.e. no connection that goes from economic growth to the insurance sector was established. Similar to that, the changes in penetration rate also lead to changes in economic growth. Here too is the connection unilateral, except in case of pene_life, where the existence of causality with gdppc was not established.

\section{CONCLUSION}

The paper examined the nature of the relationship of the insurance sector, as a part of the financial sector, and total economic activity, on the basis of panel model in six countries of former Yugoslavia for the period 2005-2019. In order to include key trends on the market insurance, in the analysis penetration rate and insurance density were used, both in total display and segmented to sectors of life and non-life insurance. Six different models were tested, and as an independent variable gross domestic product per capita was used, while the degree of trade openness of national economy was used as the control variable. Empirical results have shown that all analyzed variables are stationary after the conversion into the first difference (i.e. I(1)), as well as that in all six models the cointegration (long-term connection) of insurance sector and economic growth was established.

By analyzing long-term effects, we noticed that the density of insurance has positive and statistically significant impact on economic growth, which is expressed by the corresponding coefficient of elasticity in the range of 0.64-0.77 (depending on the applied technique). As the confirmation of robustness, the corresponding causality test has shown unidirectional causality, i.e. that the changes in insurance sector, measured by the density of insurance, cause the changes in economic growth. Also, it has been established that the density of non-life insurance has greater impact on economic activity in relation to the density of life insurance.

The results of this study can provide initial basis and certain recommendation for further development of insurance sector. Financial sectors in the analyzed countries are dominated by bank services while insurance services are the second most important. In that sense, there is a significant room for improvement in this area, and considering significant positive effects that the insurance sector has on economic growth, the holders of economic policy should pay special attention to formulating corresponding regulations and legal framework that would provide free insurance sector development, so that its basic (and derived) functions would be realized at a higher level and so that in the area of financial services it would provide significant support to bank sector. The most evident room for improvement is certainly the sector of life insurance, even in the countries that are full members of the EU. That could be 
achieved by emphasizing the importance of insurance in the context of reduction if uncertainty that the future can bring, by establishing efficient service prices, as well as by establishing a greater level of trust for the insurance sector. However, one should bear in mind the fact that the image of the average insured person in the analyzed countries corresponds to the total state of society, that implies the level of life standard, the manner of life, the level of education and culture. Thus, in the following research it would be interesting and significant to focus on the established feedback of changes in insurance and general economic activities and finding optimal balance between them.

\section{REFERENCES}

Arena, M. (2008). Does insurance market activity promote economic growth? A cross-country study for industrialized and developing countries. Journal of Risk and Insurance, 75(4), 921-946. doi: 10.1111/j.1539-6975.2008.00291.x

Breitung, J., \& Pesaran, H. M. (2005). Unit roots and cointegration in panels. Discussion Paper Series 1: Economic Studies No. 42/2005. Deutsche Bundesbank.

Breusch, T. S., \& Pagan, A. R. (1980). The Lagrange multiplier test and its applications to model specification in econometrics. The Review of Economic Studies, 47(1), 239-253. doi:10.2307/2297111

Burić, M. N., Smolović, J. C., Božović, M. L., \& Filipović, A. L. (2017). Impact of economic factors on life insurance development in Western Balkan Countries. Zbornik radova Ekonomskog fakulteta u Rijeci: časopis za ekonomsku teoriju i praksu, 35(2), 331-352. doi:10.18045/zbefri.2017.2.331

Chang, T., Lee, C. C., \& Chang, C. H. (2014). Does insurance activity promote economic growth? Further evidence based on bootstrap panel Granger causality test. The European Journal of Finance, 20(12), 1187-1210. doi:10.1080/1351847x.2012.757555

Chen, P. F., Lee, C. C., \& Lee, C. F. (2012). How does the development of the life insurance market affect economic growth? Some international evidence. Journal of International Development, 24(7), 865-893. doi:10.1002/jid.1765

Cristea, M., Marcu, N., \& Cârstina, S. (2014). The relationship between insurance and economic growth in Romania compared to the main results in Europe-a theoretical and empirical analysis. Procedia Economics and Finance, 8, 226235. doi:10.1016/s2212-5671(14)00085-9

Croatian Insurance Bureau. Insurance market in the Republic of Croatia (2005-2019). Available on: https://huo.hr/hr/publikacije/statisticke-publikacije/

Ćurak, M., Lončar, S., \& Poposki, K. (2009). Insurance sector development and economic growth in transition countries. International Research Journal of Finance and Economics, 34(3), 29-41.

Dumitrescu, E. I., \& Hurlin, C. (2012). Testing for Granger non -causality heterogeneous panels. Economic Modelling, 29 (4), 1450-1460, doi:10.1016/j.econmod.2012. 02.014

Haiss, P., \& Sümegi, K. (2008). The relationship between insurance and economic growth in Europe: a theoretical and empirical analysis. Empirica, 35(4), 405431. doi:10.1007/s10663-008-9075-2

Holtz-Eakin, D., Newey, W., \& Rosen, H.S. (1988). Estimating vector autoregressions with panel data. Econometrica, 56(6), 1371-1395. doi:10.2307/1913103 
Ilhan, E. G. E., \& Bahadir, T. (2011). The relationship between insurance sector and economic growth: An econometric analysis. International Journal of Economic Research, 2(2), 1-9.

Insurance Supervision Agency - Montenegro. Izvještaj o stanju na tržitu osiguranja (Report on the situation on the insurance market, 2005-2019). Available on: http://www.ano.me/index.php?option=com_phocadownload\&view=category \&id $=2 \&$ Itemid $=69$

Insurance Supervision Agency of North Macedonia. Annual report on the status and movement of the insurance market (2005-2019). Available on: https://aso.mk/ en/category/reports/isa-reports/

Insurance Agency of Bosnia and Herzegovina. Statistics of Insurance market (2005-2019). Available on: http://www.azobih.gov.ba/statistika/default.aspx?id=1909\&langTag $=$ en-US

Insurance Supervision Department of National Bank of Serbia. Insurance sector in Serbia (2005-2019). Available on: https://nbs.rs/en/finansijske-institucije/ osiguranje/izvestaj/index.html)

Kalaš, B. M., Mirović, V., Milenković, N., \& Andrašić, J. (2020). The impact of macroeconomic determinants on commercial bank profitability in Central and Southeastern European countries. Teme, XLIV (4), 1391-1409.

Maddala. G.S., \& Wu, S. (1999). A comparative study of unit root tests with panel data and new simple test. Oxford Bulletin of Economics and Statistics, 61(1), 631-652, doi:10.1111/1468-0084.61.s1.13

Njegomir, V., \& Stojić, D. (2010). Does insurance promote economic growth: The evidence from ex-Yugoslavia region. Ekonomska misao i praksa (Economic Thought and Practice), (1), 31-48.

Pedroni, P. (2001). Purchasing Power Parity Tests in Cointegrated Panels. The Review of Economics and Statistics, 83(4), 727-731. doi:10.1162/003465301753237803

Peleckienė, V., Peleckis, K., Dudzevičiūtė, G., \& K Peleckis, K. (2019). The relationship between insurance and economic growth: evidence from the European Union countries. Economic research-Ekonomska istraživanja, 32(1), 1138-1151.

Pesaran, H. (2007). A simple panel unit root in the presence of cross-section dependence. Journal of Applied Econometrics, 22(2), 265-312. doi:10.1002/jae.951

Pesaran, H. (2004). General diagnostic tests for cross section dependence in panels. Working Papers in Economics 0435, Cambridge.

Slovenian Insurance Association. Statistical insurance bulletin (2005-2019). Available on: https://www.zav-zdruzenje.si/kategorije-publikacij/statisticni-zavarovalniskibilten/)

Stančić, V. \& Lojanica, N. (2020). The link between insurance activities and economic growth: some evidence from emerging European countries. In: Domanović, V., \& Zlatanović, D. (Eds.): 6th International Scientific Conference on Contemporary Issues in Economics, Business and Management (213-220). Kragujevac: University of Kragujevac, Faculty of Economics.

Swiss Re Institute (2020). Sigma 4/2020: World Insurance: riding out the 2020 pandemic storm. Zurich.

World Bank (2020). World Development Indicators. Washington D.C. [November 8, 2020]

Zouhaier, H. (2014). Insurance and economic growth. Journal of Economics and Sustainable Development, Vol. 5 No. 12, 102-113. 


\title{
РАЗВОЈ ТРЖИШТА ОСИГУРАҢА И ЕКОНОМСКИ РАСТ: ПРИКАЗ ЗЕМАЉА РЕГИОНА ЗАПАДНОГ БАЛКАНА
}

\author{
Немања Лојаница, Владимир Станчић, Стеван Луковић \\ Универзитет у Крагујевцу, Економски факултет, Крагујевац Србија
}

\section{Резиме}

У раду се испитује међусобна условљеност параметара на тржишту осигурања и економског раста на специфичном подручју бивше Југославије, и укључује националне економије Словеније, Хрватске, Србије, Црне Горе, Босне и Херцеговине и Северне Македоније. Ове земље деле значајну међусобну повезаност како са економског, тако и са историјског становишта. После тродеценијског транзиционог периода након распада бивше заједничке државе, ове земље данас се налазе у различитим статусима у односу на Европску Унију (ЕУ), с обзиром да су поред земаља чланица, заступљене и оне у статусима кандидата и потенцијалних кандидата за приступање истој. Њихова тржишта финансијских услуга су релативно слична, с обзиром да су изразито банкоцентрична, а да су сектори осигурања по значају на другом месту и да их карактерише перманентан развој.

Временски хоризонт посматрања обухвата период 2005-2019. године, а као одговарајући методолошки оквир коришћена је економетрија панела. Како би се обухватили кључни трендови на тржишту осигурања, у анализи су коришћене тржишна пенетрација и густина осигурања, како у свеукупном приказу, тако и сегментирано на секторе животног и неживотног осигурања. Тестирано је шест различитих модела, а као независна променљива употребљен је бруто домаћи производ по глави становника, док је као контролна варијабла коришћен степен трговинске отворености националне економије. Емпиријски резултати су показали да су све анализиране варијабле стационарне након конвертовања у прву диференцу (I(1)). Пропратни тестови коинтеграције (Johansen-Fisher) и дугорочних ефеката (DOLS и FMOLS) су показали да су сектор осигурања и економски раст дугорочно повезани, као и да сектор осигурања врши позитиван и статистички значајан утицај на економски раст. Анализирајући дугорочне ефекте, показано је да густина осигурања врши позитиван и статистички значајан утицај на економски раст, који је изражен одговарајућим коефицијентом еластичности у распону 0.640.77 (у зависности од примењене технике). Као потврда робусности, одговарајући тест каузалности је показао једносмерну каузалност, односно да промене у сектору осигурања, мерене густином осигурања, изазивају промене у економском расту. Такође, установљено је да густина неживотног осигурања врши већи утицај на економску активност у односу на густину животног осигурања.

Резултати ове студије могу дати полазну основу, и неку врсту препорука, за даљи развој сектора осигурања у анализираном региону. Постоји значајан простор за напредак на овом пољу, а узевши у обзир значајне позитивне ефекте које сектор осигурања има на економски раст, носиоци економске политике би посебну пажњу требало да обрате на формулисање одговарајуће регулативе и законског оквира који би омогућио слободан развој сектора осигурања, а тиме и раст привредне активности. 